\title{
Imágenes en contexto: genealogía, representación social e imaginario pictórico del cuerpo femenino
}

\section{Images in their context: Genealogy, Social representation and Picture imagery of the female body}

\author{
Alejandra Val \\ Universidad Carlos III de Madrid \\ Alejandra.val@uc3m.es
}

Resumen - A través del desnudo se plantean apasionantes problemas culturales, estéticos, políticos y artísticos. El análisis genealógico de tres obras realizadas en diferentes momentos históricos y con funciones sociales muy distintas, como son la Venus de Botticelli, la Venus de Urbino de Tiziano y la Venus del Espejo de Velázquez, nos muestra cómo esos cuadros sirvieron para configurar el ideal de mujer dominante en cada época y la construcción social de la feminidad en Occidente.

Palabras clave: sociología del arte, género, representación social, desnudo.

Abstract • Through the study of art nude, the following paper will approach cultural, aesthetic, political and artistic issues. Through a genealogical analysis of three works of art, made in different historical moments and with very different social purposes, such as The Birth of Venus by Botticelli, The Venus of Urbino by Titian and The Rokeby Venus by Velázquez, we will see how the ideal figure for a woman was constructed in each period and how the social construction of femininity used to work in the western culture.

Keywords: Sociology of Arts, Gender, Social Representation, Nude.

\section{INTRODUCCIÓN}

El cuerpo desnudo ha sido - y sigue siendo- utilizado como medio para reflexionar sobre lo permitido y lo prohibido, lo deseable y lo no deseable. A través de él se plantean apasionantes problemas culturales, estéticos, políticos y artísticos: fue utilizado en la pintura para establecer y normalizar todo un sistema de proporciones; se empleó como punto de referencia para mostrar lo que era bello y lo que no lo era; se adoptó como medio para transmitir valores supremos, tales como la libertad, la justicia, la igualdad; 
se recurrió a él como objeto de intercambio diplomático e, incluso, contribuyó a que los países occidentales europeos definieran, sirviéndose de ese tipo de pinturas, su poder e identidad nacional.

En cualquier caso, la elección del desnudo como motivo artístico no es algo que surja espontáneamente de la mente del «artista». El proceso es más complejo de lo que parece, porque ¿qué funciones sociales desempeñan las pinturas de este tipo? ¿Por qué y para qué se pintan? Para responder tales cuestiones hemos adoptado una actitud empírica, hemos elegido tres obras representativas para centrarnos en su estudio y análisis. Son obras que fueron realizadas de los siglos XV al XVII por diferentes pintores y en diferentes lugares, por lo que corresponden a escuelas distintas de pintura, y son reconocidas en la historia universal del arte: El Nacimiento de Venus de Botticelli, la Venus de Urbino de Tiziano y la Venus del Espejo de Velázquez.

\section{EL NACIMIENTO DE VENUS COMO EXPRESIÓN DE LA SABIDURÍA ANTIGUA}

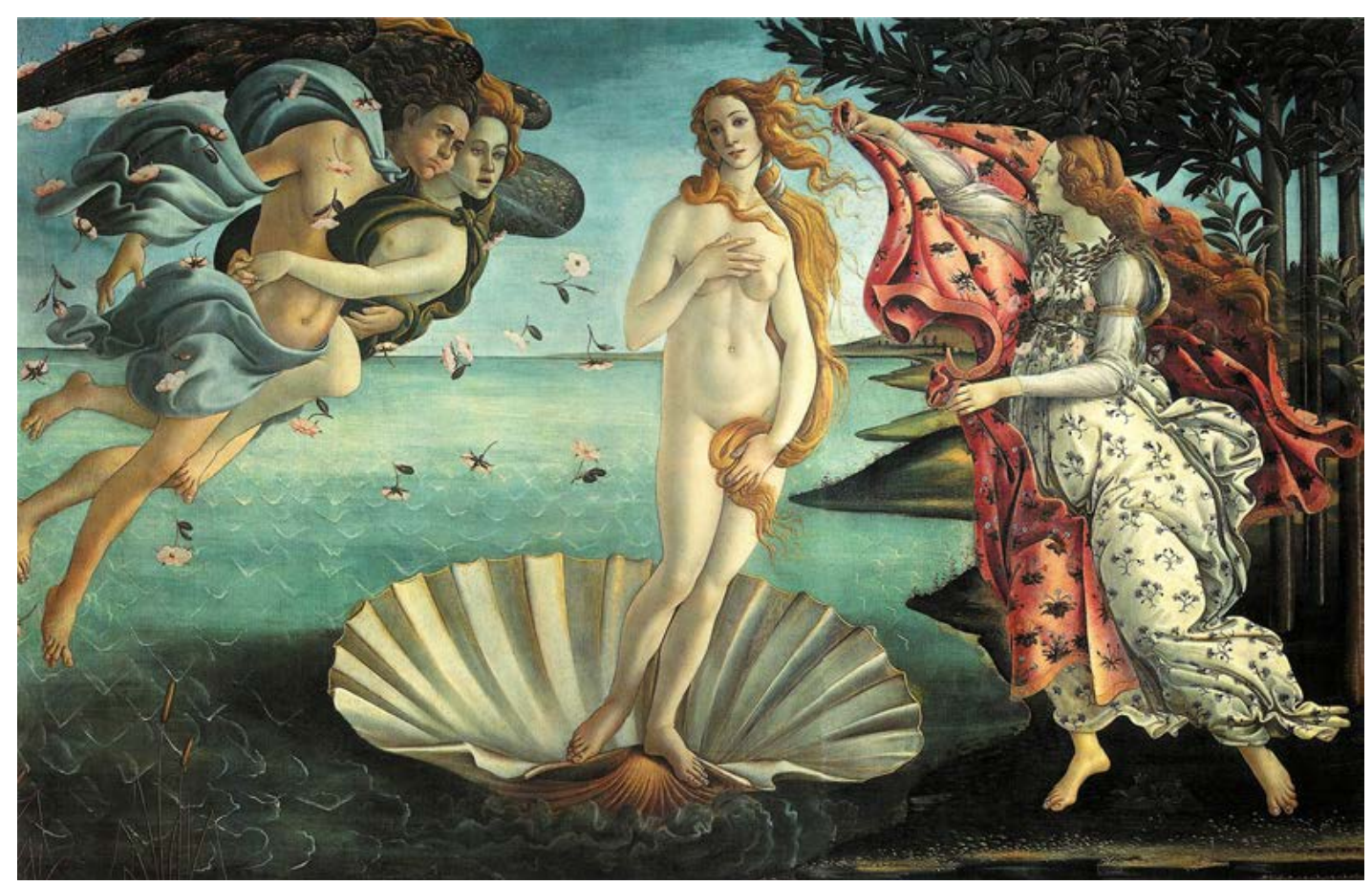

Nacimiento de Venus, Sandro Botticelli (1484-1485)

Para Panofsky, la Venus de Botticelli sería expresión de la sabiduría antigua más que de la sensualidad moderna. Gombrich es de la misma opinión, pues, en la medida en que por influjo de las ideas neoplatónicas la pintura se aproximaba al arte de la música, el objetivo común era ejercer cierto hechizo y provocar efectos filosóficos duraderos. Dicha Venus evoca el ideal ciceroniano de refinamiento y cultura y representa, por tanto, una 
metáfora de la vida moral, ya que los seres divinos se distinguían por ser prototipos ejemplares (33).

Fue Aby Warburg el primer crítico que mencionó que Botticelli tuvo el apoyo de un consejero humanista para la realización de esa obra, ya que como los artistas carecían de una educación clásica, necesitaban asesoramiento cuando les encargaban obras de contenido mitológico. Warburg destacó que posiblemente fueron el poeta Angelo Poliziano (1454-1495) y el humanista Marsilio Ficino, protegidos al igual que Botticelli por Lorenzo el Magnífico, quienes inspiraron algunos aspectos de la pintura. Poliziano debió insistir para que Botticelli añadiera en El Nacimiento de Venus los paños ondulantes y los cabellos sueltos. En el Quattrocento, el interés por la Antigüedad residía en las cualidades opuestas del movimiento "gracioso» o «apasionado». Para Warburg, el movimiento de la ninfa que parece quitarse sus ropajes en La Primavera es clave para entender la obra de Botticelli y gran parte de la producción artística del Renacimiento. La respetabilidad burguesa, si quería asumir una auténtica función de desahogo de la emoción desenfrenada, debía liberarse de los estorbos del rico brocado: sólo así podía abrir camino hacia una expresión «natural» de las pasiones humanas. El momento en el que ello se logró fue crucial en la historia del arte renacentista.

En el Renacimiento, los mecenas inventaban «temas» y pedían la colaboración de alguna persona «culta» que preparaba al artista, lo que se denominaba «programa». Según Gombrich, en la época en que fueron pintadas las obras de La Primavera o El Nacimiento de Venus, éstas no pertenecían a ninguna categoría reconocida. Existían temas mitológicos en el arte profano en cofres matrimoniales, arquillas o tapices, pero Botticelli fue el primero en pintar cuadros mitológicos que en tamaño competían con el arte religioso del siglo XV. Con El Nacimiento de Venus no asistimos a la fundación del arte profano - que había existido durante toda la Edad Media-, sino a la apertura de éste a esferas que hasta entonces habían sido exclusivas del culto religioso, temas provenientes de la caballería y del amor cortés.

En 1439 se creó en Florencia una academia neoplatónica bajo el auspicio de los Médicis, llamada Academia de Carraggi, instancia que se convirtió en el punto de encuentro entre pintores, poetas, dramaturgos y arquitectos cuyo interés común era el pensamiento de Platón y, en especial, los temas del amor y de la belleza. El contacto de esos humanistas influyó en materias como la geometría, la física, la astrología, la mitología, etc., que se vieron afectadas por la interpretación neoplatónica. El principal pensador protagonista de la academia florentina fue Marsilio Ficino, autor de importantes traducciones clásicas, como las Enéadas de Plotino y tutor personal de Lorenzo el Magnífico. Para Ficino, el deseo es lo que induce al hombre a integrarse en ese orden universal y así unirse a Dios. La belleza, junto al deseo, es lo que despierta al amor y permite a los humanos llegar a Dios. Según los teóricos neoplatónicos, la belleza expandida por el universo adquiere dos formas que están descritas simbólicamente bajo dos imágenes: la Venus Celeste y la Venus Vulgar. La obra El Nacimiento de Venus inmortaliza a la primera, mientras que La Primavera representa a la segunda. Si la Venus Celeste tiene un origen celestial es porque nace sin intervención divina de los testículos que cayeron sobre la espuma del mar cuando Urano, dios del cielo, fue castigado por Saturno. La Venus Vulgar es fruto del amor entre Júpiter y Juno, y por ello, al tener madre, contiene materia y habita en una esfera inferior, el alma cósmica. Es esa belleza la que se muestra accesible a nuestro sistema de percepción y la que produce en nosotros un gran deleite visual. Ambas Venus no son dos 
versiones que se contraponen, sino que se complementan. Para los seguidores de Platón, tales figuras no designan dos formas opuestas de amor, uno casto y el otro sensual, sino dos amores nobles llamados amore celeste e humano, siendo el segundo una imagen humilde del primero (Raquejo, 69-70).

Ficino vio la esencia del amor a partir de un dualismo formado por el deseo corporal y el anhelo espiritual dirigido a Dios, porque para él la significación del amor suponía la fecundación de las ideas platónicas por la fe cristiana. Al definir la belleza como «esplendor del rostro de Dios», volvió a reafirmar la identidad entre lo bello y lo bueno. El amor es siempre engendrado por una belleza que por su propia naturaleza llama «el alma de Dios». Si bien el amor es siempre deseo, no todos los deseos son amor: sólo cuando el deseo se hace consciente de un fin último merece el nombre de amor. Y siendo esta virtud última esa bondad divina que se manifiesta en la belleza, el amor tiene que ser definido como «un deseo del goce de belleza» (Panofsky, Renacimiento, 200).

El mecenazgo de la familia Médicis comenzó hacia 1470, cuando Botticelli retrató a Piero de Médicis, hijo de Cósimo y padre de Lorenzo el Magnífico. Pero el encargo más importante antes de que pintara El Nacimiento de Venus y La Primavera fue el de decorar la habitación nupcial del hijo de Antonio Pucci, Giannozzo, que iba a contraer matrimonio con Lucrecia. En Florencia, se acostumbraba a decorar las casas de los nobles con casetones de madera que tenían por nombre spallieras, cuya función era proteger del frío y de la humedad las habitaciones principales. Lorenzo de Pierfrancesco (14631503), primo de Lorenzo el Magnífico, encargó a Botticelli tres cuadros de contenido mitológico: La Primavera, El Nacimiento de Venus y Palas y Centauro. Mientras en la primera Venus aparece cubierta con un ligero manto, en el segundo aparece desnuda. En La Primavera, la diosa simboliza la Venus Vulgar, el amor humano, mientras que en El Nacimiento representaría la Venus Celestial. Pero no debemos entender a la Venus Vulgar como una diosa sensual, al margen de la celestial, ya que el amor humano tiene la capacidad de ver en la belleza corporal, la belleza celestial. Ambas son una sola, la belleza divina que ha descendido al mundo natural, y se diferencian del amor ferinus o bestial, que es un amor brutal, violento, irracional. Botticelli y su mecenas entendían El Nacimiento de Venus como una alegoría moral y de saber astrológico.

La Venus del Renacimiento, por lo tanto, no es sólo una diosa del placer, sino que abarca la humanitas, que a su vez engloba el amor, la caridad, la liberalidad y magnificencia, la gentileza y la modestia, la dignidad, el encanto y el esplendor. El significado de humanitas como valor procede de Cicerón, quien señala que es la cualidad que distingue al hombre no sólo de los animales, sino también de quien pertenece a la especie homo sin que por ello haya de merecer el calificativo de homo humanus: el bárbaro o el hombre vulgar faltos de pietas (Raquejo, 85). La concepción renacentista de ese término presentó, desde el principio, un doble aspecto, supuso la renovación de la clásica antítesis entre bumanitas y barbaritas y la supervivencia de la antítesis medieval entre humanitas y divinitas. De esta concepción ambivalente de humanitas se ha originado el humanismo, el que, para Panofsky, se puede definir como fe en la dignidad del hombre, fundada en la reafirmación de los valores humanos (racionalidad y libertad) y en la aceptación de los límites del hombre (falibilidad y fragilidad) (Renacimiento, 18-19).

El Nacimiento de Venus de Botticelli representa algo más que un simple desnudo. En el ángulo superior izquierdo dos personajes alados y enlazados soplan: el moreno es Eolo, el viento frío del huracán, el rubio y de aspecto más delicado es Céfiro, la brisa suave. 
En el lugar central, Venus, de pie sobre una concha, sobre una venera, se cubre el pecho con la mano derecha y con la izquierda sujeta un mechón de la cabellera rubia con la que oculta su sexo, a la vez que se desliza a la orilla, donde la Hora de la Primavera esparce un manto de flores para recibirla, al tiempo que las rosas que surgen del aliento de los céfiros perfuman el espumoso mar. El tema proviene de Las Metamorfosis de Ovidio, que describe a la Hora en el momento de ir a tender una mano a Venus. Otra fuente literaria puede ser el poema de Poliziano "La Giostra», que había sido utilizado por el pintor en otra de sus obras mitológicas, La Primavera. También el relato de Hesíodo vincula la diosa al mar, de donde la hace nacer.

A juicio de Gombrich, la obra mostraría el nacimiento de la bumanitas, engendrada por la naturaleza con sus cuatro elementos; aire, agua, tierra y fuego, así como la unión del espíritu con la materia. El autor ha encontrado en El Nacimiento de Venus una relación entre el nacimiento de la diosa y el bautismo de Cristo. También Panofsky ha señalado que la propia Venus podría ser tomada como una virgen de la Anunciación, debido a la similitud que existe entre sus rasgos y los de las Madonnas de Botticelli. Para F. Saxl, el pintor pudo haberse basado en una pintura de Baldovinetti, El bautismo de Cristo; Gombrich presupone que la puerta de Ghiberti del Duomo de Florencia también pudo sugerirle la composición de El Nacimiento de Venus, e incluso Peter Burke ve esta pintura como un intento de reconstrucción de las obras perdidas del pintor griego Apeles (26).

Para la cultura del siglo XV, la figura de Venus iba más allá de la representación de un simple cuerpo femenino, a través de la figura desnuda de la diosa se estaba haciendo presente toda una concepción vital, toda una manera de entender la belleza, el hombre y el cosmos (Camamis, 159-182).

\section{LA VENUS DE URBINO DE TIZIANO COMO SOPORTE PRIVILEGIADO DE EROTISMO}

Tiziano es el pintor por antonomasia del siglo XVI veneciano. En esa ciudad, el sentido de refinamiento que adquirieron las maneras cortesanas tuvo grandes repercusiones en el arte y en la forma de representar el desnudo femenino. Por ello la escuela veneciana de pintura fue tan solicitada, porque representaba como ninguna otra la delicadeza, la elegancia y el lujo tan estimados por las clases altas.

Tiziano contó con el mecenazgo de las familias más ricas de Venecia y Roma, entre las que se encontraban el duque de Ferrara, el duque de Mantua y, a partir de 1530, el emperador Carlos V. En 1533, fue nombrado pintor de la Corte por este último y se le concedieron los títulos de Conde Palatino y Caballero de la Espuela Dorada, tanto para sí como para sus descendientes. La mayoría de los historiadores del arte coinciden en el carácter erótico de las obras de Tiziano. Fernando Checa manifiesta que los cuadros de desnudos femeninos del pintor italiano excluyen cualquier interpretación neoplatónica, para centrarse en las características físicas del desnudo de Venus. Según Checa, la Venus de Urbino es una pintura erótica con complicadas elaboraciones simbólicas de carácter moral o político (99), donde el sentimiento moral y erótico de la pintura de Tiziano no se contraponen. Pierre Civil participa de la misma idea, cuando afirma que los temas mito- 
lógicos fueron utilizados en el siglo XVI como un pretexto y un soporte privilegiado de erotismo (41). El historiador también entiende el cuadro Venus de Urbino como un canto al placer, al atribuir a la Venus rasgos y atributos que transcienden el lenguaje mitológico, como el manto rojo - color representativo de la nobleza veneciana- que hay detrás de la figura desnuda, las dos sirvientas y el interior de la casa.

A juicio de la historiadora feminista Virginia Allen, Venus se convierte a partir del siglo XVI en objeto sexual, a través de las pinturas de Giorgione y más tarde de Tiziano. Porque si hasta el siglo XIV las mujeres tenían la posibilidad de estudiar Derecho en las universidades de Bolonia o París y Medicina en Salermo, a partir de esa fecha empezaron a ser excluidas de los estudios universitarios, que pasaron a ser específicamente masculinos. En contrapartida, el matrimonio se convirtió en el «estado perfecto" al que debía aspirar toda mujer y su educación debía girar en torno a la familia.

Esas imágenes femeninas repercutieron tanto en las mujeres como en los hombres. A las mujeres porque a través de ellas se les decía: «esto es lo que tú eres», y a los hombres justamente por lo contrario: «esto es lo que ella es». Virginia Allen comenta que la tensión sexual que se vivía desde mediados del siglo XVI queda reflejada en el cuadro Concierto Campestre de Giorgione y en Venus con organista de Tiziano. En ambas pinturas la figura masculina aparece vestida y la femenina desnuda, símbolo de que las mujeres están al servicio de los hombres (29).

Pese al conflicto de interpretaciones, parece ser cierto que la Venus de Urbino está basada en la Venus de Giorgione. Y aunque el tema de la Venus dormida no figura en la mitología ni en la literatura clásica, Giorgione pudo inspirarse en el episodio del descubrimiento de Ariadna por Baco, que trata el tema de la belleza en sueños contemplada por su amado. Entre ambas pinturas existen algunas diferencias claves: la primera está despierta, mientras que la segunda está dormida; una se encuentra en el interior de una estancia y la otra en plena naturaleza.

La Venus de Urbino es una obra realizada para la conmemoración de un matrimonio, el de Guivaldo della Rovere y Giulia Varano, en 1534. En el Renacimiento, esta celebración era un evento social cargado de simbología. Cuando una pareja se desposaba, el anillo que la familia del novio otorgaba a la novia sellaba el contrato nupcial, pero la alianza matrimonial no se daba por concluida hasta que el ajuar de la novia llegaba a la casa del esposo - el mismo día o el día después de haberse celebrado la boda-, lo que confirmaba que el matrimonio se había consumado. El ajuar de la novia se guardaba en cassoni, pequeños cofres decorados con escenas mitológicas (Olsen, 6). Eso es exactamente lo que se nos muestra en la obra de Tiziano, una mujer desnuda, con la mirada dirigida al espectador (¿o quizá a alguien que está en el cuadro, pero que permanece invisible?), mientras que, en un segundo plano, dos doncellas guardan el ajuar en los cassoni ofrecidos por el marido a su esposa.

Pero, ¿por qué motivo los esposos se regalaban cuadros de desnudos? ¿En qué lugar se colocaban tales pinturas? En el siglo XVI, existía la costumbre de decorar las habitaciones conyugales con cuadros de ese tipo, porque ayudaban a nacer a criaturas sanas, bellas y fuertes, pues la contemplación de la belleza estética engendraba belleza física. Estos cuadros únicamente se regalaban en los enlaces matrimoniales de las clases altas, la aristocracia, las familias reales y la alta burguesía (Freeberg, 3). Por ese motivo se elegían escenas mitológicas que significaban fidelidad y fertilidad. Dentro de la mitología, había temas que se consideraban más representativos que otros de la lascivia o del amor, de la 
fertilidad, etc. El contacto con el seno, por ejemplo, era un motivo iconográfico frecuente, metáfora del acto sexual que se utilizó con relativa asiduidad en los siglos XVI, XVII y XVIII, y el tema de Dánae y Júpiter, así como el de Venus y Vulcano, se entendían como alusiones a los peligros de la infidelidad conyugal.

El cuadro de la Venus de Urbino no es un caso único. Otras pinturas que se utilizaron como regalos nupciales fueron Lot y sus hijas, de Francesco Furini, que el duque de Toscana regaló al rey Felipe IV, en 1649, con motivo de su boda con Mariana de Austria, o la Venus de Tiziano, regalo del monarca Felipe II a su prometida, María Tudor, con la que se casaría en 1554. La pintura Amor Sagrado, amor profano (1514-1515) también se pintó para festejar el matrimonio de Niccolò Aurelio con Laura de Bagarotto y tiene como antecedente La Primavera de Botticelli (1492) y El Nacimiento de Venus (14841485). Las dos reflejan distintos grados de belleza y suscitan amores diferentes, pero ambas - según Ficino- «son nobles y dignas de ser honradas, pues las dos, cada una a su manera, engendran la belleza».

En la Venus de Urbino, la figura femenina más que taparse el sexo con la mano izquierda parece que lo está acariciando. Esa es otra de las razones por las que ha sido vista con implicaciones lascivas. Sin embargo, el concepto de sexualidad y de masturbación no tenía —en el siglo XVI- el mismo significado que en nuestros días. Para Galeno, como para otros médicos de la época, la masturbación femenina era deseable, porque favorecía la procreación. Gabriel Falloppio, profesor de Anatomía en Padua a mediados del siglo XVI, opinaba lo mismo. Para Tiziano, castidad y sexualidad no son dos aspectos antagónicos sino interactivos (Goffen, 78). Otra peculiaridad en la obra de Tiziano es la presencia de un perro. En los entierros de los nobles medievales era frecuente esculpir a los pies del caballero o de la dama un perro, que simboliza la fidelidad, la amistad y la protección. Este animal volverá a aparecer en cuadros de otros pintores y llegará hasta la conocida Olympia, de Manet, aunque transformándose en gato, animal que Baudelaire puso de moda porque lo consideraba símbolo de modernidad. Pero ver la Venus de Urbino como una obra similar a la Olympia de Manet es olvidar cuatro siglos de historia social.

La misma modelo que posó para la Venus de Urbino lo hizo para La Bella (1536), que fue adquirida por Francesco Maria della Rovere ese mismo año. Rona Goffen admite que, posiblemente, las modelos que posaron para Tiziano fueran prostitutas (72), pero, como señaló Julia Varela, bajo esa rúbrica se tienden a confundir a las mujeres de las clases populares, ya que su «libertad sexual» aún no había sido codificada ni domesticada por el proceso de recristianización que suponen la Reforma y la Contrarreforma.

Para Gombrich, en los ochenta años que separan las obras de Botticelli y Tiziano hay un enorme aumento de habilidad: no sólo de representación, sino también de técnica. Si Botticelli no dominaba aún del todo el problema anatómico - lo que se puede ver en las correcciones que realizó del pecho, del brazo y del hombro-, para Tiziano la representación del cuerpo desnudo ya no era un problema (35). Tiziano dio un sentido especial al «acto de mirar», empleó colores cálidos y vivos y golpes de pincel gruesos como borrones, atentado contra el dogma clásico de pintar al natural. Pero esos «golpes de pincel» o «manchas distantes» por los que los seguidores de Miguel Ángel atacaban a Tiziano fueron justamente utilizados por Quevedo para alabar las pinturas de Velázquez, cuya obra Venus del Espejo comentaremos a continuación. 


\section{LA VENUS DEL ESPEJO DE VELÁZQUEZ. ¿UNA VISIÓN IRÓNICA DE LA MITOLOGÍA?}

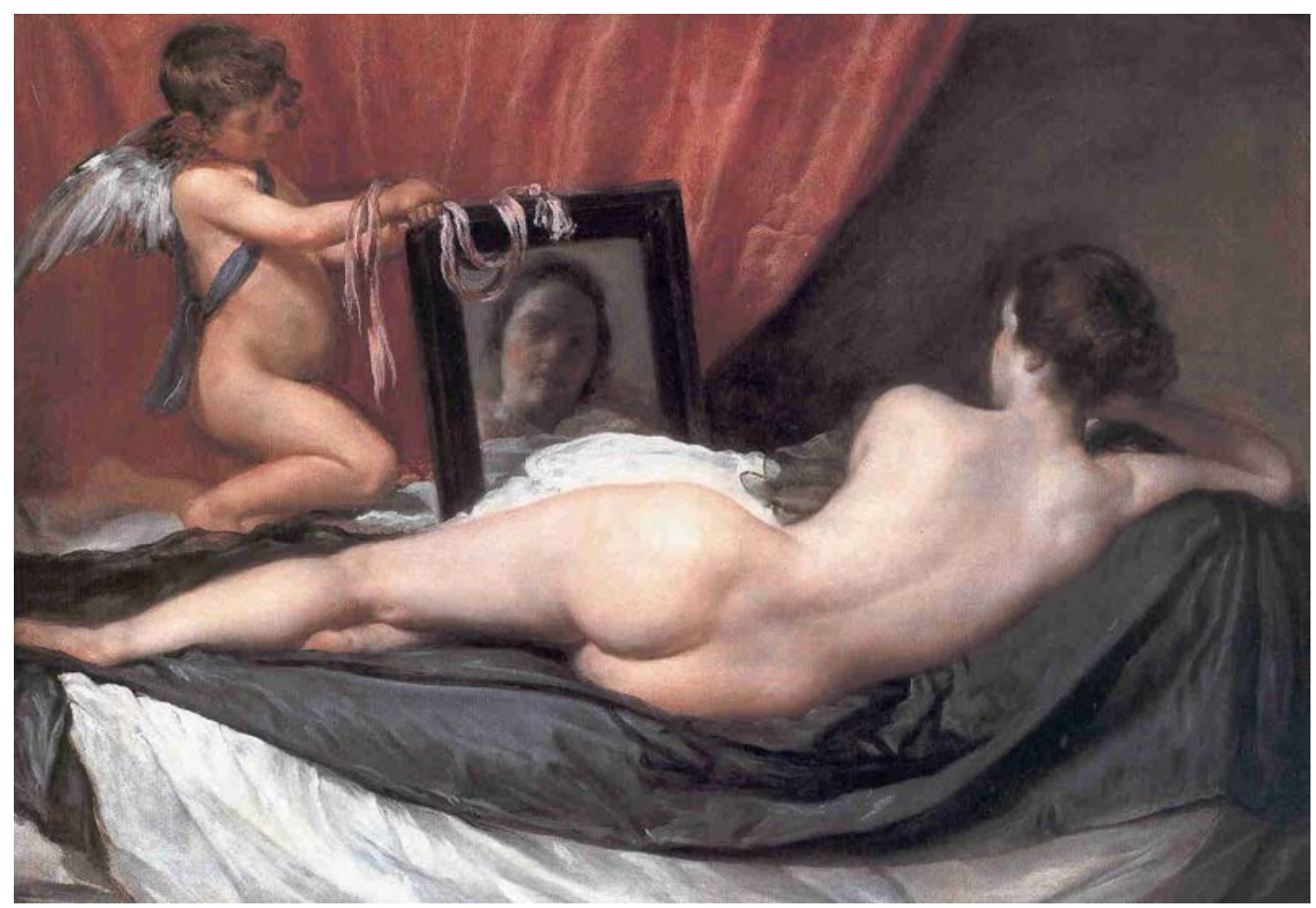

Venus del espejo, Diego Velásquez (1647-1651)

Si hasta finales del siglo XVI se exige al artista sujeción a la idea de naturaleza y de belleza, en el XVII ambas exigencias se contraponen, porque el significado mismo de naturaleza se altera. La pintura de Velázquez cambia con respecto a los siglos anteriores, pues «el ser artista» se entiende de una manera nueva. Las obras de Tiziano y de Velázquez son diferentes porque "pintar» significa una cosa distinta para cada uno de ellos, cambio en el que tiene mucho que ver el desarrollo de la ciencia moderna con los descubrimientos de Galileo, Copérnico, Descartes, etc. y con las nuevas reglas que rigen el campo del saber.

En la época de Velázquez, la profesión de artista gozaba en general de una mayor consideración social, lo que les permitía contar con una mayor libertad y originalidad a la hora de hacer sus obras. Seguía habiendo numerosos pintores que además de ejercer como tales teorizaban sobre el significado de la pintura, como es el caso de Palomino, Carducho y Pacheco, a quienes ya nos hemos referido.

De Velázquez sabemos que era un hombre culto y que, si bien no dominaba todas las ciencias citadas anteriormente, se interesaba por las matemáticas, la mecánica, la anatomía, la medicina, la perspectiva, la arquitectura, la historia y la arqueología. Según José Antonio Maravall, los textos más destacados de su biblioteca no eran los de un 
humanista, sino que, «separándose de las letras del humanismo, se orienta hacia una preocupación moderna, buscando información sobre un conocimiento científico de la naturaleza y del hombre» (39).

En el Renacimiento se venía pensando que la belleza y la perfección de una persona o de una cosa, conforme a las cuales es apta para ser convertida en objeto de representación artística, no están tanto en su ser íntimo como en el puesto social que ocupa o en el conjunto en que se inserta. Según el historiador Maravall, cuando «Brueghel y otros flamencos empiezan a pintar escenas populares, no se les ocurrirá representar en ellas figuras de mujeres hermosas y no porque no supieran captar la elegancia o hermosura femeninas, sino porque los presupuestos ideológicos de la época, los grandes valores de belleza y virtud sólo podían darse entre los altos» (122-123). Por ello tenemos que pensar lo que significó que un artista como Velázquez se rehusara a reflejar lo bello e introdujera en sus pinturas a los tullidos y enanos de la Corte. El pintor ya no modela figuras de acuerdo con el paradigma de belleza renacentista. «En Velázquez, la hermosura o la fealdad, la gracia o la torpeza, la elegancia o la deformidad, son de cada persona» (124). Él renunció a la pretensión del idealismo, tratando de captar de la naturaleza sólo lo necesario. Y como los espectadores aún no estaban acostumbrados a ello, tenían la impresión de que sus cuadros estaban inacabados.

Velázquez es uno de los primeros ejemplos de un pintor «vocacional»: pintó lo que quiso o, por lo menos pudo hacerlo en mayor medida que los otros pintores, ya que su empleo en el palacio y la relación de amistad que tenía con Felipe IV, lejos de coartarle esa autonomía, se la facilitó. Apenas contaba veinticuatro años cuando fue nombrado pintor del rey, en 1623: "Desde ese momento no acepta prácticamente encargos, pinta lo que el rey le manda, y el rey le manda muy pocas veces» (Ortega y Gasset, 35). En 1652 solicita el cargo de "aposentador mayor», puesto destinado a la nobleza. En 1658, el rey le manifiesta su voluntad de premiarle y le concede un hábito de las órdenes militares. Velázquez elige el hábito de Santiago, pero antes de serle concedido, se procede a una prueba de limpieza de sangre y de hidalguía familiar, donde los testigos deben afirmar que Velázquez no ha ejercido nunca el oficio de pintor, que ha vivido siempre en el decoro y que su pintura es un don y no una manera de vivir.

En el Renacimiento, la mitología expresaba lo fundamental de la preocupación por lo humano. Los pintores y poetas hacían uso de las fábulas mitológicas para descubrir el sentido de lo humano que se encierra en el saber antiguo, considerándolas como objeto propio de los studia humanitatis. La mitología servía para mostrar virtudes y defectos, propiedades de las cosas que halagaban a los poderosos y guardaban oculto un sentido alegórico y transcendente sólo perceptible por unos pocos. Pero fueron justamente escritores y artistas del XVII, como Góngora, Velázquez y Quevedo, los que por primera vez utilizaron las fábulas mitológicas de forma burlesca (Ortega y Gasset, 163). Velázquez pintó varios cuadros con esa temática, entre los que destacan Los borrachos, como alegoría de una escena báquica, La fragua de Vulcano, Marte, Argos y Mercurio, Las Hilanderas y La Venus de espaldas. El pintor manifiesta una «actitud» moderna, trata de romper con la tradición, y ello se observa perfectamente en la Venus del Espejo, cuadro en el que difumina la silueta del rostro y lo reduce a unas cuantas manchas, como había hecho en Las Meninas y en Las Hilanderas.

Don Gaspar Méndez de Haro, marqués de Eliche, le encargó la Venus del Espejo en 1651. En el inventario del Duque de 1670, ya se conoce como La Venus, la cual aparece 
descrita de la siguiente manera: «una pintura en lienzo de una muger desnuda tendida sobre un paño pintada de espaldas, recostada sobre el brazo derecho mirándose en un espejo que tiene un niño de la mano de Velásquez de dos varas y media de ancho y una y media de cayda con su marcho negro» (Morán y Checa, 297-298). Gaspar de Haro tenía colgada la Venus de Velázquez en el techo de una de las habitaciones de su casa y cuando su colección pasó a pertenecer a la familia de Alba, tras el matrimonio de su única hija, la marquesa de Carpio, con el duque de Alba, compartió sala con otra Venus de Corregio. A partir de 1800 aparece en el inventario de la colección de Godoy como regalo de la propia duquesa. En ese mismo año, Céan Bermúdez y González Sepúlveda visitaron su colección y este último anotó en su diario que en el gabinete había varias Venus colgando: «en una pieza o Gavinete interior están cuadros de varias Venus, ay la famosa de Velázquez que le regaló la Duquesa de Alba, y la compañera de Jordan. Ay una desnuda de Goya pero sin dibujo ni gracia en el colorido, ay otra chica a pastel, parece copia aunque no en el todo de Tiziano, tal vez sea de la Marquesa de Santa Cruz que fue quien se la dio» (Morán y Checa, 300).

En 1808, coincidiendo con la invasión napoleónica, la colección de Godoy le fue expropiada y se subastó. La Venus del Espejo fue adquirida por el agente inglés Buchaman, en 1813. Posteriormente pasó a las manos de John Morritt en 1815, y desde 1906 hasta la actualidad se puede apreciar en la National Gallery de Londres. La historia de la Venus del Espejo no termina aquí. En 1914 fue acuchillada por Mary Richardson, una feminista que vio en ella una imagen que reflejaba de manera clara el sometimiento de la mujer en el arte y que se exponía, por tanto, para perpetuar la sumisión en la vida social.

Aunque es el único desnudo de Velázquez que ha llegado hasta nosotros, parece que pintó otros dos, Venus y Adonis y Cupido y Psique, que sirvieron para decorar las estancias del Alcázar de Madrid. El espejo vendría a representar la fugacidad de la vida y de la belleza. Por los estudios que se han hecho, parece que la figura del Cupido fue añadida más tarde y que originariamente el pintor no se propuso hacer un personaje mitológico. También se ha planteado la hipótesis de que La Venus de Velázquez se había pintado como réplica de otra Venus: si en la primera se mostraba una mujer de espaldas, en la segunda se habría representado una mujer de frente. Esta es la conjetura a la que han llegado Duncan Bull y Enriqueta Harris, al mencionar que la misteriosa compañera fue adquirida por el pintor en uno de sus dos viajes a Italia. Desde 1651 hasta 1813, ambas obras parecen haber conformado una pareja de Venus. Se desconoce el autor de esa doble imagen, porque los distintos inventarios la citan como original de Tiziano, de Luca Giordano, de Padovanino y de Pordenone, que es como la denominó el copista Richard Cooper (645).

Al parecer, Velázquez se basó en dos esculturas clásicas que había visto en su viaje a Italia, La Ariadna, perteneciente a la familia Médicis, y el Hermafrodita, de la familia Borghese. El tema de la Venus de espaldas no es exclusivo de este pintor, cuadros similares formaban parte de la colección de Felipe IV, especialmente la Venus y Adonis de Tiziano o Júpiter e Io de Corregio, e incluso la Toilette de Venus de Rubens.

Tampoco la técnica del espejo era nueva en su obra, pues ya se aprecia en Las Meninas, donde aparecen difuminados en el espejo los rostros de los monarcas. En cual- 
quier caso, es una pintura excepcional por su perfección técnica, por su belleza y por la escasez de obras de ese tipo pintadas por un español. La Inquisición castigaba la introducción y exhibición de imágenes lascivas con la excomunión, 500 ducados y un año de destierro y prohibía que los pintores trataran el tema. Como ya hemos señalado, Palomino, pintor y teórico español del siglo XVII que obtuvo el título personal de censor de la pintura, mencionó que se debía distinguir entre «lo desnudo y lo deshonesto y mucho más lo lascivo», a lo que Palomino añadía que «la rareza del desnudo femenino puede excitar con la novedad la atención y de ahí el peligro». El censor de la pintura recomienda a los pintores «la lectura del Ovidio y el Teatro de los dioses, sólo para que comprendieran mejor los cuadros de los palacios, no por los asuntos que se les pudiesen encargar».

Para el historiador alemán y especialista en la pintura de Velázquez, Carl Justi, el cuadro no gustó a Pacheco, maestro y suegro de Velázquez, quien aconsejaba utilizar modelos femeninos sólo para el rostro y las manos, valiéndose para lo demás de fuentes secundarias. Justi, en su detallado estudio sobre Velázquez, manifestó que la modelo que posó para «la Venus de Espaldas era de tipo español, y que se ha querido reconocer en el modelo a la muchacha de Las Hilanderas» (595). Hay otros estudiosos del pintor que mantienen que la modelo fue la pintora italiana Lavinica Triunfi, a quien Velázquez conoció en su segundo viaje a Roma, y no faltan los que opinan que fue la comedianta Damiana, amante del marqués de Heliche (Iñaguiez, 189).

El tema del espejo sigue planteando todo tipo de especulaciones; el empleo de este objeto proviene de una preocupación que tardó casi toda su vida en resolver y en dominar: la perspectiva especular. El espejo sirve a Venus para mirarse y a nosotros para ver su rostro, pero, ¿es ópticamente correcto el planteamiento pictórico? Según el historiador Ángel del Campo y Francés, Venus no puede verse en el espejo y el espectador no puede verla tal y como aparece reflejándose en él, aunque el pintor nos lo haga ver como posible (53). La imagen reflejada en el cuadro sería menor que la real por hallarse más distante; no es correcto ni el tamaño de la cara ni el ángulo con el que nos mira. Velázquez sabía que su planteamiento era engañoso: su intención era mostrarnos una Venus que se veía a sí misma, por eso hizo dar al espejo una postura vertical y oblicua. El genial pintor se inventó una perspectiva que no existía en la realidad.

Observamos que existen dificultades a la hora de captar el sentido de la Venus de Velázquez, pues la mayor parte de los analistas la consideran una obra enigmática. El artista pudo romper con los moldes pictóricos de su época por varios motivos: en primer lugar, por su propio estatuto ambiguo, ya que pasó de ser un pintor artesano a ser el pintor favorito de la Corte. Ese estatuto especial le abrió nuevas posibilidades frente a otros pintores e influyó en sus formas de percibir el mundo y de reflejarlo. Su vida también coincidió con cambios importantes, no sólo en lo que se refiere a técnicas y estilos pictóricos, sino también a transformaciones en el ámbito del saber: fue en ese momento cuando el pensamiento mágico-mítico comenzó a declinar, al mismo tiempo que se inicia el pensamiento racionalista, un régimen del saber en el que domina la transparencia del signo, la búsqueda de una correspondencia entre los signos y las cosas. 


\section{A MODO DE CONCLUSIÓN}

Tres lecturas del cuerpo femenino desnudo que contribuyeron - al igual que otras producciones culturales- a configurar el ideal de mujer dominante en cada época. El desnudo femenino en la historia de la pintura occidental ha jugado funciones sociales distintas dependiendo de cada época y de cada situación social, pero también es cierto que todos esos cuadros comparten un sustrato común: crear la ficción de que la identidad femenina es objetivable. Las distintas formas de representar a «la mujer desnuda» influyeron en la elaboración de la condición femenina misma, son imágenes que ayudan a comprender la construcción social de la feminidad en Occidente. El desnudo femenino parece corroborar la tesis defendida en la obra el Nacimiento de la mujer burguesa, de Julia Varela, al poner en evidencia que una de las piezas del dispositivo de feminización es esa relación que se establece entre naturaleza y cuerpo femenino y cultura y cuerpo masculino. Este proceso de naturalización que comienza en el Renacimiento es muy importante para la visión que de la mujer se tendrá en los siglos posteriores. El régimen visual que instituyó el Humanismo supuso una codificación de los gestos y maneras de presentarse y representarse. En sus tratados artísticos, en sus obras literarias y en sus manuales de urbanidad, los humanistas describieron toda una serie de posturas femeninas ideales. "La mujer» se convierte en objeto de la mirada masculina. En el Renacimiento, el cuerpo se transforma en un objeto expresivo que los espectadores cultos pueden descodificar. Uno de los mejores ejemplos artísticos es la proliferación, en todo el siglo XVI, de la imagen artística de la mujer tumbada, imagen que reenvía a los cuadros de naturalezas muertas, más en concreto a los bodegones, con su compleja significación de belleza que está consumiéndose, que está fresca y viva pero sólo por un instante, que es objeto de deseo y a la vez que recuerda la caducidad de la vida, la muerte.

Los humanistas crearon la idea del «ciudadano», asignándole una serie de derechos y deberes. Pero diferenciaron claramente los atributos que correspondían al «hombre» y a «la mujer». "La mujer» será elevada por poetas y artistas a la categoría de ideal, mientras que los humanistas la inscribieron dentro del hogar y del matrimonio católico indisoluble. La aparición de las universidades y academias de arte fue decisiva para la creación del ideal femenino. A partir del funcionamiento de las universidades cristiano-escolásticas, los «oficios» en los que hasta entonces habían participado mujeres (traductoras, médicas, pintoras, etc.) van a ser sustituidos por «profesiones universitarias» a las que ellas no tienen acceso. De esa manera, las puertas de la educación institucional se abrieron para unos y se cerraron para otras. Los pintores se apropiaron de unos saberes como la geometría, la anatomía y la medicina, que les otorgaron el privilegio de recrear ese cuerpo femenino, mientras que la mujer gozó en el mundo artístico de un papel secundario y no demasiado valorado: se convirtió en «modelo» y, como las características de ese trabajo se contradecían con los presupuestos mantenidos por la Iglesia Católica, su profesión se comparó con la prostitución. Pero, en el mismo momento en que se establecen comparaciones entre el posar y el prostituirse, las obras de desnudos femeninos empezaron a ser uno de los temas destacados en las colecciones de una minoría culta, quienes vieron en esos retratos una manera de diferenciarse del resto de la población. 
Los desnudos femeninos no sólo expresan un modo de entender el mundo, sino que además formaron y forman parte de una política cultural y también de una cultura política que tiene un fuerte impacto en la redefinición social de los sexos.

\section{REFERENCIAS}

Allen, Virginia. «The naked lady: A look of Venus in the Renaissance». The Feminist Art Journal 6 (1977). 27-29. Medio impreso.

Álvarez-Uría, Fernando y Julia Varela. Materiales de sociología del Arte. Madrid: Siglo XXI, 2008. Medio impreso.

-. Genealogía y sociología, materiales para repensar la Modernidad. Buenos Aires: El cielo por asalto, 1997. Medio impreso.

Baxandall, Michel. Painting and experience in XV century Italy. Oxford: Clarendon Press, 1972. Medio impreso.

Bull Duncan y Harris Enriquetta. «The Companion of Velázquez's Rokery Venus and a source for Goya's naked Maja». Burlington Magazine (1986). 643-645. Medio impreso.

Burke, Peter. El Renacimiento italiano. Cultura y Sociedad en Italia. Madrid: Alianza Editorial, 2001. Medio impreso.

Calvo Serraller, Francisco. La Teoría de la Pintura del Siglo de Oro. Madrid: Cátedra, 1981. Medio impreso.

—. Velázquez. Barcelona: Península, 1999. Medio impreso.

Campo y Francés, Angel. «La Venus de Velázquez». Academia 78 (1994). 53-66. Medio impreso.

Canamis, George. "The concept of Venus-Humanitas in Cervantes as the key to theEmigma of Botticelli's Primavera». Bulletin of the Cervantes Society of America 2 (1988). 47-70. Medio impreso.

Civil, Pierre. «Erotismo y pintura mitológica en las España del siglo de oro». Edad de Oro IX (1990). 39-50. Medio impreso.

Checa, Fernando. Tiziano y la monarquía hispánica. Madrid: Nerea, 1994. Medio impreso.

Freeberg, David. El poder de las imágenes. Madrid: Cátedra, 2009. Medio impreso.

Goffen, Rona. Titian's Women. New Haven: Yale University Press, 1997. Medio impreso.

Gombrich, Erving. Textos escogidos sobre arte y cultura. Madrid: Debate. 1991. Medio impreso.

Justi, Carl. Velázquez y su siglo. Barcelona: Itsmo, 1999. Medio impreso.

Maravall, José Antonio. La cultura del Barroco. Barcelona: Alianza editorial, 2000. Medio impreso.

Marsicano, Edward. The femme fatale myth: Sources and manifestation in selected visual media 1880-1920. Ann Arbor: Emory University, 1984. Medio impreso. 
Morán, Miguel y Fernando Checa. El Coleccionismo en España. Madrid: Cátedra, 1985. Medio impreso. Medio impreso.

-. El arte de mirar. La pintura y su público en la España de Velázquez. Madrid. Istmo, 1997. Medio impreso.

Morán, Miguel. Tiziano. Madrid: Historia 16, 1993. Medio impreso.

Olsen, Christina. "Gross expenditure: Botticelli's Nastagio degli Onesti Panels». Art History 15:2 (1992). Medio impreso.

Ortega y Gasset, José. Velázquez. Barcelona: Espasa Calpe, 1999. Medio impreso.

Panofsky, Erwin. Estudios sobre iconología. Madrid: Alianza editorial, 1972. Medio impreso.

- Renacimiento y renacimientos en el arte occidental, Madrid: Alianza editorial. 1993. Medio impreso.

Portus, Javier. «Fray Hortensio Paravicino: La Academia de San Lucas, las pinturas lascivas y el arte de mirar». Espacio, Tiempo y Forma 9 (1996). 77-105. Medio impreso.

Raquejo, Tonia. Sandro Botticelli, Madrid: Historia 16, 1993. Medio impreso.

Snow, Edward: «Theorizing the male gaze, some problems». Representations 25 (1989). Medio impreso.

Varela, Julia. Nacimiento de la mujer burguesa. Madrid: La Piqueta, 1997. Medio impreso.

Recepción: 6 de julio de 2010

Aceptación: 26 de enero de 2011 